\title{
The politics of border and nation in Nepal in the time of pandemic
}

\author{
Mallika Shakya ${ }^{1}$ (D) \\ Published online: 7 August 2020 \\ (C) Springer Nature B.V. 2020
}

As most of South Asia faces a surge in COVID-19 incidence following the end of a 3-monthlong lockdown setting off a public uproar about a states' inability to respond to the pandemic with empathy and effective policy measures, it is timely to reflect on the changing geopolitics of borders in the region, and its implications for the future of nationalism and humanitarianism especially for two countries Nepal and India which are currently engaged in an intense border conflict triggering speculations about internal power-shuffling as well as bilateral diplomacy.

This dispute involves a 40-square kilometre stretch of land on Nepal's far-western border with India which is not far from China. Unwittingly, this border dispute came immediately ahead of the violent face-off between the Indian and Chinese military in the Galwan Valley just over $500 \mathrm{~km}$ from the disputed territory with Nepal, resulting in the death of 20 Indian soldiers. It should be noted however that the Nepal-India border dispute is not new by any means; it can be dated back to the 1816 treaty that Nepal was forced to sign with the colonial British administration following a 2-year violent war, a treaty which conceded about one-third of Nepal's territory to the British Empire.

My proposition in this commentary is that this ongoing border dispute, also known in Nepal as the Kalapani dispute, should be read within the contexts of (i) the 1990 regime change in Nepal following the end of the Cold War, (ii) the India-Nepal standoff amid Nepal's promulgation of its 2016 constitution which brought a formal closure to the People's War waged by its Maoist rebels and (iii) the rising heavy-handedness on part of the Nepali state especially during the country-wide lockdown involving the COVID-19 crisis.

I also wish to remind the readers that while India continues to receive extensive coverage in most global policy and media platforms as well as academic deliberations, the same cannot be said about its smaller neighbours including Nepal. This commentary presents a nonhegemonic account of Nepal's growing border tensions with a bigger neighbour India in the context of the India-China face-off whose roots can be traced to the end of the Cold War and an unprecedented rise of neoliberal capitalism in South Asia in the 1990s.

Mallika Shakya

mallika@sau.ac.in

1 Department of Sociology, South Asian University, Akbar Bhawan, Chanakyapuri, New

Delhi 110021, India 


\section{The 2020 border dispute: the tip of an iceberg}

On June 13, 2 months after it imposed a strict national lockdown, the Nepalese House of Representatives unanimously endorsed the Second Amendment to the constitution of Nepal to update the country's new political map in its national emblem. The bill was endorsed unanimously by the Upper House the day after. The cabinet had issued the concerned map on May 20 which incorporated Limpiyadhura, Lipulekh and Kalapani, a 370-square-kilometre strip on its far west frontiers disputed with India, within Nepal's borders (Ghimire 2020).

India reacted strongly to this. Its army chief General MM Naravane made a public statement that Nepal "might have raised this problem at the behest of someone else" thus implying an alleged Chinese role. ${ }^{1}$ India's Ministry of External Affairs stated that Nepal's revised map included parts of Indian territory and urged Kathmandu to correct this "unilateral act" and "to respect India's sovereignty and territorial integrity". The right-wing media in India openly claimed that Nepal had taken the "drastic" moves on Kalapani to "appease" China through the latter's aggressive offensive against India. Some far-right media journalists even raised sexist and misogynist speculations about a possible "honey-trap" involving the role of Ms. Hou Yanqui, the Chinese ambassador for Nepal known for her bold diplomacy. ${ }^{2}$

The mainstream media in India distanced itself from such misogynist attacks but treated this border dispute with outrage and anticipated a strong Indian backlash. On June 12, when an Indian citizen was killed and three others injured in the Nepalese side of the border in Sitamadhi, some $1000 \mathrm{~km}$ southeast of the disputed Kalapani territory, the Indian media was quick to link this with the Kalapani dispute and anticipate a military escalation from the Indian side. The diplomats from both countries later clarified that the Sitamadhi incident was not a military dispute but a local law and order matter involving the enforcement of the COVID-19 lockdown (India Today 2020).

Two days later, as a violent face-off erupted between the Chinese and Indian military forces on the Galwan Valley in Ladakh - about $500 \mathrm{~km}$ northeast of the site of Nepal-India dispute - killing 20 Indian soldiers and triggering a major backlash from the opposition party within India, its diplomats came forth to suggest that it is within India's interest to reconcile the matter with Nepal than to escalate, and that disputes with Nepal should not be entwined with the embroiling dispute with China. In an interview with Karan Thapar, a former NSA advisor and a seasoned Nepal expert Shivshankar Menon, responded to a question suggesting a Chinese role in Nepal's standoff with India by saying "Nepal is a friendly neighbour with whom we have intimate ties of various kinds and we should deal with it accordingly rather than mixing it up into a much more complicated and difficult and larger geopolitical problem" (Thapar 2020).

The intellectuals and the civil society activists in both countries echoed and fed in to the mainstream media narrative: On May 8, 2020, the Indian defence minister virtually inaugurated an $80-\mathrm{km}$-long road which had been recently built to facilitate a Hindu pilgrimage to the

\footnotetext{
${ }^{1}$ See NDTV news broadcasted and also tweeted on May 15. https://twitter. com/ndtv/status/1261305804654698504 (accessed on 7 July 2020)

2 Just 2 days after a video clip went viral in Nepali social media, of an Indian television journalist suggesting that PM Oli might have been "honey-trapped" by Hou Yanqi, the Chinese ambassador to Nepal, Nepal's cable and satellite television providers stopped airing Indian news channels to register their objection to this. The Kathmandu Post, the largest English daily in Nepal, wrote a sharp editorial on 9 July 2020, objecting to a "vicious disinformation campaign [against PM Oli and Ambassador Yanqi] run by a section of the right-wing, nationalist Indian television media in the past few weeks".
} 
sacred Mount Kailash on the Chinese/Tibetan side of the Himalayas, and by doing this, it also established a strategic land link between Delhi and the Tibetan plateau. The Chinese side recognised the Indian sovereignty in this stretch of land by agreeing to expand trade through the Lipulekh pass even when Nepal had routinely registered its opposition to this road project from the point of its construction in 2008. Basu (2020) was among the few intellectuals from India who acknowledged a 26-year-long series of discussions between Nepal and India on this dispute. A veteran Indian Marxist intellectual and Nepal expert Anand Swaroop Verma went a step ahead to clarify that Kalapani and Lipulekh are Nepalese territory which India had "borrowed" from Nepal to set up an army camp during the 1962 Sino-Indian war (Indo-Nepal News 2020).

From the Nepali side, historian Ramesh Dhungel referred to the maps issued by the colonial Survey of India in 1850 and 1856 which had clearly stated that the source of the border river Mahakali was Limpiyadhura - and not the Lipu Khola (a small tributary) as is now being claimed by the current Indian establishment - thus clarifying that the entire disputed territories did belong to Nepal (Thapa 2020). Several civil society activists and political leaders connected this border dispute with previous political conflicts where India had leveraged on its border control to put pressure on Nepal (Shrestha 2003; Jacob 2020).

In 2015, as Nepal promulgated its constitution which formally brought a closure to its Maoist rebellion, an unofficial blockade was imposed by India for over 4 months amid Indian reservation that the new constitution did not adequately address its concerns. Popular grievance against India's blockading move stirred a nationalistic current in Nepal which later resulted in a massive election victory for the Nepal Communist Party (NCP) led by the current Prime Minister KP Oli.

Earlier in 1989, when the bilateral trade and transit treaty expired, India officially sealed its borders with Nepal for over 13 months resulting in acute shortage of fuel and other everyday household goods throughout the country. The blockade ended only after Nepal had a regime change that ended King Birendra's direct rule and ushered in multi-party democracy in Nepal. The 1992 constitution promulgated by the democratic parliament made headways for an ambitious economic liberalisation programme in Nepal so much so that the World Bank declared Nepal a "best practice" on its Structural Adjustment Programme within few years of democratisation. A young generation in Nepal grew up equating democracy with neoliberal capitalism and consumeristic freedom, thereby triggering an unprecedented wave of the commodification of land, labour and money (Shakya 2018).

\section{Power crisis in the ruling communist party in Nepal}

Just 2 weeks after the much-hyped new map was enshrined on the national emblem of Nepal, Prime Minister Oli who had led through this grand nationalistic mustering seemed certain to be unseated, not by those in the opposition party but the opposition within his own Nepal Communist Party (NCP). It is important to remember that NCP had been founded just 2 years ago through a merger of the two major streams of the communist movement in the country: one which had aligned itself with the liberals to oust monarchy and usher in multi-party democracy in Nepal (i.e. the Communist Party of Nepal-United Marxist Leninist, or the CPN/ UML) and the other which had waged an armed rebellion against the democratic alliance (i.e. the Communist Party of Nepal-Maoist Centre, or the Maoists).

NCP's permanent committee meeting held on July 1, 2020 concluded that PM Oli must resign obeying the party whip. The former Maoist party President Prachanda who had chaired 
this meeting warned that PM Oli (earlier from CPN/UML) must resign if he wanted to "save the unification of the two communist parties". Oli's supporters responded that such a move will force the Prime Minister to dissolve the ongoing parliamentary sessions and also register his own new party. Rumours were rife that a new CPN/UML had indeed been registered anonymously in the Election Commission under suspicious circumstances, and the formerly dissolved CPN/UML leaders might have had a role in this. ${ }^{3}$

The story of anti-Oli stance within NCP is not simply a rift between the two communist factions. Several NCP leaders from the democratic stream (or UML) openly sided with former revolutionary Prachanda to demand PM Oli's resignation both from national premiership and party chairmanship. Allegations were made against Oli about corruption, crony capitalism and unilateralism. Several protests ongoing in the Kathmandu streets overlooking global guidelines about social distancing raised a gamut of issues ranging from serious lapse of law and order in public COVID-19 quarantines to massive corruption in sourcing of public medical supplies, and a spate of caste and gender violence. PM Oli, known for his unrelenting satires against the opposition, came under pressure in both public and social media for his denial of the severity of COVID-19 in Nepal and dismissal of humanitarian concerns raised both by the opposition party and the civil society.

His own comrades accused PM Oli of functioning through a narrow coterie and acting unilaterally without party consultations. The internal debate on whether or not to sanction a massive foreign aid package under the Millennium Challenge Corporation (MCC) was particularly acrimonious. However, the biggest objection raised by the Party permanent committee during the July 1 meeting was that PM Oli had publicly alleged his fellow comrades of sabotaging his cabinet at an Indian behest. Media hyped in its reportage of the July 1 NCP meeting that Comrade Prachanda had directly confronted PM Oli by saying, "it is not India who is asking for your resignation, it's me demanding it" (Dhakal 2020). Several consultations were held between Comrade Prachanda and PM Oli following this confrontation, and the power corridors in Kathmandu were rife with rumours that the Chinese ambassador had been very active behind the scenes mediating between the two rivals. Within the public sphere, the country saw few mass rallies in support of PM Oli and demanding that NCP leaders play politics based on policy than individual showmanship ("neta haina neeti hera").

\section{Lockdown and the politics of border}

The corona virus caught Nepal off guard. Despite having a thick aviation network with China, ${ }^{4}$ possibilities of a COVID-19 crisis had not really been discussed in Nepal until February. On February 15, 2020 when Nepal mustered a grand nationalistic gesture by evacuating 175

\footnotetext{
${ }_{3}^{3}$ As far as the PM's resignation was concerned, political commentators in Nepal mulled that a sitting prime minister may resign only after losing a no-confidence motion in the parliament, and that the communist tradition of a party committee demanding the resignation of the sitting Prime Minister was not democratically binding. After reports surfaced of PM Oli sending a messenger to the largest opposition party Nepali Congress, its spokesperson formally clarified that this meeting was not about forming a new coalition cabinet and that the Nepali Congress will not take over the government even if PM Oli resigned.

${ }^{4}$ There are over 90 flights arriving at Kathmandu every week from various Chinese cities. As far as land border is concerned, however, although Nepal shares a long border with China, much of it is sealed by the high Himalayas. Also, unlike its border with India which is one of the few "open borders" in Asia where citizens of both countries can crisscross without any formal reporting whatsoever, China and Nepal have maintained strict border surveillance especially after the Tibet crisis of 1949.
} 
Nepalis, mostly students, stuck in the Chinese province of Hubei, the returnees were put in strict quarantine, and with this, the young secular republic seemed to wash off its hands from all public duties involving the pandemic. It did nothing for the next 5 weeks to restrict the incoming international traffic, not only from China but also the rest of Asia and Europe. Any suggestion that flights from China should be suspended was seen as an anti-China — and by extension anti-Communist—voice.

On February 18, as part of its regular reporting on the global scenario on COVID-19, the leading national daily carried an opinion piece by Ivo Daalder, a former US Ambassador to NATO, condemning that China's secrecy had made the corona virus crisis worse for the world. This article was previously published in the Seoul-based Korea Herald, and with it came a stock photo showing Mao Tse Tung donning a surgical mask. This was met with a sharp criticism from the Chinese embassy in Kathmandu. Initially came a sharp tweet from the Chinese ambassador Hou Yanqi, and later the Chinese embassy in Kathmandu issued a formal statement on the same day which criticized that article for "..ignorance and prejudice on China, [and that the reproduction of that image in the TKP had] deeply hurt the feelings of the Chinese people..." A group of 17 Nepali editors affiliated with various media houses in Kathmandu collectively denounced the Chinese statement (Chhetria Patrakar 2020; The Wire 2020).

The situation changed dramatically within a month. As the WHO declared COVID-19 a pandemic and India suspended all international flights, Nepal followed suit on March 19. Four days later, it temporarily sealed its borders both with India and China, bringing to a halt all onfoot, informal border-crossings especially on its open border with India. The country-wide lockdown declared on March 31, initially for a week but extended till mid-June and further continued in partial forms for the next month, dramatically altered everyday life on its border towns especially involving migrant workers who had crossed thisopen-border to seek livelihood abroad.

India's tragedy about migrant workers being caught off guard and having to walk several hundred kilometres to their hometowns is well documented (Vasavi 2020). In the wake of the country-wide lockdown, Nepal saw similar exodus on part of its own internal migrant workers although these were not widely reported. No concerted efforts came out of the civil society including trade unions towards helping the migrant workers on their perilous journey. As the bourgeois middle class turned its blind eye to this, the state easily shrugged off the woes of the migrant labour as a "necessary evil" to save the country from Corona virus.

Instead, as the media highlighted that all of the five cases of COVID-19 reported in Nepal in March were "imported" and that the migrant workers returning from India may potentially be COVID-19 carriers, the border surveillance became stricter. PM Oli made an off-the-cough remark in the Parliament that $85 \%$ of the corona virus cases in Nepal had come from India. Few footages circulated of some Nepalis sneaking into their villages by crossing the Indian borders through green fields and rivers without notifying the authorities. Further, global media narratives of "super-spreaders" added stigma and fear of the "foreign-returnees" in Nepal (Shrestha 2020). Bundled up with class discrimination, the migrant workers became an especially suspicious demographic category who had to be contained and kept away in order to keep the bourgeois middle class safe. A series of draconian police crackdowns were unleashed both on the Nepal-India border and in Kathmandu. Even then, the government hardly addressed the burning issue that there were very few public quarantines and test centres, and that the national stocks of PPEs and ventilators were grossly inadequate.

On April 1, Al-Jazeera produced a sensational coverage of a man who had swam across the bordering Mahakali river risking his own life, only to surrender to police arrest as he landed on 
the bank. He boldly spoke of the sufferings of hundreds stranded on the other side of the border with inadequate food and medical facilities "sleeping like animals on the ground", and urged that the country needed to save them (Shrestha 2020). This raised concerns about over two million Nepalis working in India, many working as low-wage labourers, but the government kept the borders sealed. Only on June 3 Nepal and India opened 20 border points to allow their stranded citizens to cross the border and come home.

Further concerns were raised as the pandemic swept through the Gulf States, and measures were taken to expel the already-repressed migrant workers without any care for their repatriation. In early July, Nepal facilitated nine repatriation flights to evacuate thousand or so Nepali citizens, mostly migrant workers who had been stuck in Qatar, UAE, Saudi Arabia, Kuwait, the Maldives and Malaysia. More repatriation flights are being scheduled in the following weeks. For a country that relies on remittance to cover $32 \%$ of its GDP and with an estimated 1.3 million Nepalis working in the Gulf States, evacuation of a couple of thousands is clearly too little and too late. Even so, there is very little public cry about this in Nepali media and among political and social activists.

\section{COVID-19 nationalism: governance and protest}

Nepal had mustered a grand nationalistic gesture mid-February when it evacuated the 175 Nepalis stuck in Hubei. That nationalistic euphoria went decisively downhill as Nepal registered several COVID-19 cases within the country and imposed a country-wide lockdown mid-March.

The lockdown was harsh, and the public saw the police act increasingly brutally towards those who could not afford to confine themselves within private homes. But the state was in denial about Covid19 economics, and no measures had been taken to provide even a bare minimum cushioning to help those who lost livelihoods because of the lockdown. This gross oversight did not raise much criticism from the elite, and it seems that the global grammar of lockdown had already accomplished its coercive justice on the working poor in Nepal.

The rhetoric about COVID-19 being a "foreign" disease stirred stigma against the "foreignreturnees" thus leading to sheer neglect of the plight of the low-wage labourers, especially Dalits, who also bear the double brunt of class and caste discrimination. Reports came in June that a 16-year-old Dalit worker from a Nepal-India border town had died in the isolation ward after several weeks in a badly catered public quarantine which denied him even a packet of oral rehydration solution as he lay in bed suffering from diarrhoea after having undertaken a 1919$\mathrm{km}$ journey from Ahmedabad on foot. ${ }^{5}$ Another Dalit citizen had died in police custody under suspicious circumstances. The Dalit Struggle Committees took up both these issues and staged protests.

As the Black Lives Matter protests swept through Euro-America, several public intellectuals and social activists spoke about violence against Dalits in Nepal. Kathmandu intellectuals openly condemned two particularly gruesome incidents that had recently occurred. During the lockdown, six young men had died in mob attack in a remote district as Navaraj BK (a Dalit) sought to meet his girlfriend from the higher caste who he wanted to persuade to marry him. A 13-year-old Dalit girl Angira Pasi was found hanging from the tree after the community

\footnotetext{
${ }^{5}$ Raju Sada's relatives claimed that he had died because of the neglect by the hospital while the hospital claimed that he was under treatment in the isolation for encephalitis.
} 
leaders of her home town ordered a 25 -year-old man of a higher caste who had raped her to marry her as his "punishment". However, this wave of Dalit movement did not gain much momentum.

Instead, a youth-led protest to sweep through Kathmandu took the banner "enough is enough" to raise attention on a sheer lack of government policy and programme on corona virus. Frustrated with the forced confinement to their homes for 3 months in the name of COVID-19 control, the urban — and arguably elite - youth staged "socially distanced" protests to hold the government accountable for the COVID-19 mismanagement. The government essentially dismissed these protests and continued financial opaqueness in its disbursement of COVID-19 funds. When asked in the parliament where the government had spent the 10 billion Nepali rupees of COVID-19 funds, PM Oli shrugged off the question by saying that the focus right now should be on fighting the corona virus and not petty financial calculations. ${ }^{6}$

Another round of public rallies, mostly staged on the Nepal-India border towns, protested a bill on Citizenship Act which would make it mandatory for foreign women married to Nepali men to wait for 7 years before they can apply for Nepali citizenship and passports. While the state argued that a 7-year waiting period would make Nepali citizenship provision commensurable with India's, opposition parties criticized that the bill is targeted against the border communities who have traditionally married across the border.

\section{Post-pandemic border and nation}

Just a few months ago, "lockdown" was a word unheard by majority of Nepalis, and "quarantine" was something associated with pets than humans. While the elite Nepalis closely following the global media lead on COVID-19 had enough time to digest the new global grammar of lockdown and social distancing, the lower strata were caught off guard as a country-wide lockdown was imposed abruptly with draconian measures restricting people's movements. The state did not consider the lockdown's effects on the working poor who immediately lost their livelihoods. No relief measures were announced for those who had nothing to eat. The middle class being confined within their homes meant that no people-topeople aid came forward for the poor, thus breaking the chain of cultural charity which had historically stepped in when the government did not do enough.

The global grammar of COVID-19 seems to have unleashed a degree of totalitarian ambitions in democratically elected governments elsewhere and in Nepal. A case in point is the overnight shutting of the open border between Nepal and India and rapid withdrawal of public transport in countries where less than $1 \%$ of the population own a private car. Thousands of Nepali migrant workers were caught off guard on the Indian side of the border after they had walked thousands of miles to return home from various Indian cities when they had earlier migrated to work. The police on both sides treated migrant workers brutally, forcing them to spend months in hazardously run quarantine centres. There was very little coverage of the border miseries in the national media.

For a country so heavily invested in foreign remittance, it is ill-advised to have turned a blind eye on the repatriation of its migrant workers. Instead of rescuing its citizens stuck

\footnotetext{
${ }^{6}$ He was also mocked in social media for dismissing corona virus fears by stating that Nepalis have a strong immunity system due to their food habits and geographic location at the foot of the Himalayas which apparently produced cool and healthy air that would save people from the corona virus (himal ma thokieko cheeso hawa).
} 
abroad in dire circumstances and rehabilitating them with dignity, the government seems to indulge in empty rhetoric that Nepalis must now "go back to the basics" and repopulate "beautiful mountains with fresh air". No policies or programmes have been announced to address the concerns of those who were forced to work in the Gulf and Malaysian factories after finding mountain-living back home simply unsustainable.

Grave concerns should also be raised about the political lull which unleashed ultranationalistic ambitions among those who are ruling. The Modi government in India deemed it timely to inaugurate a Hindu pilgrimage route in the middle of its own lockdown despite knowing this would trigger border disputes with its neighbours. Nepal responded with equal grit, building on the kind of inward-looking ultra-nationalism which had brought PM Oli to power in the first place and strengthened his position within his own party following the Indian border blockade of 2015. It did not help that China seems set to adopt a policy of gaining strategic advantage on its neighbours especially on sensitive fronts such as military control of acrimonious borders.

The open border between Nepal and India built around the concept of "bride and bread relations" is probably the biggest casualty of the COVID-19 pandemic as the popular acrimony about the new map played in the hands of brazen showmanship of PM Modi in India and PM Oli in Nepal. As of today, India has surpassed Russia to become the third worst-affected country by the corona virus pandemic, and Nepal is registering an explosive rise in the number of COVID-19 cases. As worrying as it sounds, COVID-19 has not received the kind of public concern as it should. Instead, the public discourse both in Nepal and India is so much more about the hollow national prides than the actual measures of public safety and humanitarian relief measures for those who lost their livelihoods.

\section{References}

Basu, Tapan Kumar. (2020). The Kalapani Imbroglio: Has India Pushed Nepal Too Far? The Wire. https://thewire.in/south-asia/kalapani-india-nepal . Accessed 7 July 2020.

Chhetria Patrakar. (2020). A Picture of Malicious Intention. On the Chinese Embassy's Undiplomatic Letter to a Nepali Newspaper. HIMAL Southasian, February 19, 2020.

Dhakal, Ameet. (2020). Sahakarmika Taukoma PM Olile Jhundyayeko Adhyadesh ko Talwaar! [The Sword of Ordinance PM Oli has Hanged on His Co-Worker's Head!. In Setopati.com. https://www.setopati. com/opinion/210408 (accessed on July 7, 2020).

Ghimire, Binod. (2020). Constitution amendment bill to update Nepal map endorsed unanimously at the Lower House. The Kathmandu Post, June 13, 2020. https://kathmandupost.com/national/2020/06/13/constitutionamendment-bill-to-update-nepal-map-endorsed-unanimously-at-the-lower-house (accessed on July 7, 2020).

India Today. (2020). India-Nepal Tensions Peak: What's Causing the Strain in Relationships in Newstrack with Rahul Kanwal. https://youtu.be/3H2uSJACzqs (accessed on July 7, 2020).

Indo-Nepal News. (2020). Kalapani is a Part of Nepal: Anand Swaroop Verma, May 23, 2020. https://www. youtube.com/watch?v=vgJP5EheY5o (accessed on July 7, 2020).

Jacob, Happymon. (2020). National Security Conversations with Happymon Jacob: India-Nepal Cartographic Tussle - with Kanak Mani Dixit and Rakesh Sood. The Wire. June 21, 2020. https://www.youtube. com/watch?v=BnF27uJIXos (accessed on July 7, 2020).

Shakya, Mallika. 2018. Death of an Industry: The Cultural Poitics of Garment Manufacturing during the Maoist Revolution in Nepal. Cambridge: CUP.

Shrestha, Subina. (2020). Hundreds of Nepalis Stuck at the Indian Border amid Covid19 Lockdown News/Nepal. Al-Jazeera, 1 April 2020.

Shrestha, Buddhi Narayan. 2003. Border Management of Nepal. Kathmandu: Bhumichitra Publications.

Shrestha, Prasiddhi. (2020). Memoirs of the 'Super-Spreader'. Setopati.com April 19. 2020. https://www.rajan. com/calendar/convertn.asp (accessed on 9 July, 2020). 
Thapa, Saroj. (2020). Lipulekh is Ours, The Government Must Not Shake Feet (Lipulekh Hamro Ho, Sarkaarle Khutta Kamaaunu Hundaina: Interview with Historian Prof Dr Ramesh Dhungel In Himalaya Television's Daily Discussion Series Samaya Sandarva. https://www.youtube.com/watch?v=DA6S7xQpfPY (accessed on July 7, 2020).

Thapar, Karan. (2020). Chinese Behaviour Has Been Very Different From Anything In the Past: Former NSA Shivshankar Menon. The Wire. June 18, 2020. https://thewire.in/external-affairs/shivshankar-menoninterview-china (accessed on July 7, 2020).

The Wire. (2020). Nepali Editors Condemn Chinese Embassy for Statement Criticising Newspaper". Staff reporting. The Wire. 19 February 2020. https://thewire.in/south-asia/nepali-citizens-anand-teltumbdegautam-navlakha-arrest-statement (accessed on June 13, 2020).

Vasavi AR. (2020). India's Lockdown Tragedy: Bleeding Along the Fault Lines of a Nation. Corona Times. 23 June 2020. https://www.coronatimes.net/india-lockdown-tragedy-fault-lines-nation/ (accessed on 2 August, 2020).

Publisher's note Springer Nature remains neutral with regard to jurisdictional claims in published maps and institutional affiliations. 